\title{
5
}

\section{Politics, Ideology and Legal System Reform in Northeast Asia}

\author{
JOHN K M OHNESORGE
}

\section{INTRODUCTION}

HIRTY YEARS AGO, in their seminal critique of the law and development movement of the 1960s and 1970s, Trubek and Galanter called for evaluation of law and development projects in a new mode, which they referred to as 'eclectic critique' (Trubek and Galanter, 1974). Eclectic critique called for participants in legal development projects to recognise and leave open to scrutiny their assumptions about law and its complex relationships to politics and society, both at home and in the societies they were trying to assist. Trubek and Galanter focused primarily on challenging over-optimism on the part of law and development practitioners, who uncritically accepted the selfcongratulatory story of Western liberal legality, while also being too ready to assume that the same story could be replicated in the Third World. Although Trubek and Galanter focused on over-optimism, the logic of their argument applies equally to criticisms of external efforts to influence national legal systems. To the extent that such criticisms target the substance of law reform efforts rather than the methods by which they are pursued, critics risk making a mistake in the same category as the targets of Trubek and Galanter, ie that of assuming the eventual (negative) impact of law reforms with a greater certainty than is justified.

This chapter is an exercise in eclectic critique, and focuses on two sets of legal reforms that have been under way in Northeast Asia-Japan, South Korea, and Taiwan-for the past several years. Although the importance of foreign influences in bringing about these reforms is a question that will not be focused upon here, these reforms are of the type that the US government and international financial institutions-the World Bank, the IMF, the Asian Development Bank, etc-have been advocating around the world. An eclectic critique of these reforms may be useful then, regardless 
of the exact confluence of forces, domestic and international, that has brought them about in Northeast Asia. The goal is to provide a framework for exploring the interests and ideologies of those supporting legal reforms in Northeast Asia, and beyond.

\section{JUDICIALISING REFORMS TO NORTHEAST ASIAN ADMINISTRATIVE LAW AND CORPORATE GOVERNANCE}

In terms of legal development initiatives, we seem to be living in an age not merely of legalisation and institution-building, but of judicialisation, the tendency to submit greater areas of social and political life not merely to law, but to law as interpreted and enforced by the courts in cases adjudicating private rights. Judicialisation is not synonymous with legal reform, as many reforms involve rule changes or institutional innovations that do not greatly increase the role of the courts in governance. Judicialisation insists instead that courts be at the centre of governance processes, readily available to enforce rights claims put forth by private actors. The hallmark of judicialisation initiatives is that they seek to bring about social change by harnessing the energies of private litigants, channelled through the litigation process.

It would be an exaggeration to say that countries around the world are eager to adopt judicialising legal reforms, because these reforms are often supported by external pressures of substantial force, but a wide range of countries appear at least willing to undertake such reforms. Observers of this trend describe it in different ways. Some speak of a spreading of Western legal culture (Friedman, 1990), while others talk of spreading the rule of law. Some look to invigorated judiciaries as key to facilitating private economic activity, or to enforcing 'credible commitments' to restrain the 'grabbing hands' of government (Ohnesorge, 2003). Well before the Asian Crisis of the late 1990s it was clear that Northeast Asia was not immune to the forces of judicialisation; judicialising legal reforms were well underway in the region by the early 1990s. The Asian Crisis certainly advanced the process, however, as will be shown below.

This chapter explores two areas of judicialising legal reform that appear quite important in Northeast Asia: shareholder derivative litigation and administrative law reforms. Given the centrality of both government agencies and corporate hierarchies in post-World War II Northeast Asia, it would be surprising if the legal regimes that structure and control these hierarchies were not targeted by societal interests seeking political and social change. As is well-known to students of Northeast Asian law, both these areas of law have indeed become targets of legal reform in the last decade. What is seldom explicitly explored, however, is the alignment of 
foreign and domestic interests that favour reforms in these areas, and the assumptions that underlie the way these interests articulate their visions for reform.

The objective of this chapter is not to map doctrinally the details of these reforms, but to provide a framework for thinking about the interests and ideologies of those supporting the reforms. Legal reforms are by definition attempts at social engineering through law, and it is beyond dispute that the history of such attempts is riddled with failures and unintended consequences. But is there a real alternative to social engineering through law? Even those Americans who yearn for the Anglo-American golden age of common law hegemony (see eg, Epstein, 1995) would, in order to get from here to there (from the existing situation to their ideal), have to undertake a series of concrete reforms which would be as prone to failures and unintended consequences as any other radical attempt at social engineering through law. Those who engage in legal reform efforts enter the process with not only a set of goals but also a set of assumptions, stated or unstated, concerning the likelihood that the concrete legal changes they advocate will result in the social effects they desire. Where legal reforms are supported by societal coalitions that seem to hold substantially differing political views, it is natural to ask which elements within the coalition are likely to achieve their aims, once the social effects of the reforms become clear, and which will be disappointed. In the spirit of eclectic critique this chapter explores this set of questions in the context of Northeast Asia.

The reforms discussed here seek: (i) to invigorate administrative law to provide broader rights for private parties to participate in the administrative process, and enable the use of the courts to challenge administrative activities; and (ii) to invigorate the rights of minority shareholders by increasing shareholder access to the courts. Although in many respects these reforms appear unrelated, they can both be understood as reforms designed to loosen existing power relationships, shifting power from bureaucratically organised hierarchies-government agencies and corporate management-to private interests and to non-management, minority shareholders. More specifically, the private sector/civil society will be empowered vis-à-vis corporate management and government bureaucracies through the creation or enhancement of private rights, enforceable in courts. These power shifts are thus to be facilitated by judicialisation, and to the extent that courts are called upon to define the scope and contours of these newly-created rights, judicialisation also involves a power shift in favour of the judiciary.

A second characteristic these reforms share is that each can be understood as responding to two seemingly distinct sets of concerns or constituencies, a pairing that will be used to structure this chapter. One set of concerns, referred to here as the 'Neoliberal', reflects interests in limiting 
bureaucratic discretion, limiting government regulation of markets, and maximising the exercise of economic and property rights by private actors. The second set of concerns, here termed 'Populist/Progressive' (P/P), focuses on openness, accountability, and 'voice' in government as well as in corporate behaviour. Such a typology of course represents an oversimplification, as these are ideal-type ideological or rhetorical positions, and particular individuals, as well as groups, may well hold some mixture of these positions, even within themselves. Indeed, the strength of Northeast Asia's legal reform agenda may well be the extent to which it is supported not merely by coalitions of groups holding different views, but by groups and individuals to which all of the views are at least somewhat attractive. Notably, it is no objection to this analysis to argue that there is in fact no problem needing to be solved through legal reform, as Professor Ramseyer says of Japanese corporate governance and the rise of derivative litigation there (Ramseyer, 2003). A demonstration that there was no 'real' problem to be addressed would only make the existence of a broad societal coalition supporting legal reform that much more interesting.

Neoliberal and P/P tendencies or commitments tend to be mirrored by, and to mirror, external demands for legal reform. Minority shareholder rights, for example, are championed by foreign equity investors, who want their recently acquired rights to engage in portfolio investment in Northeast Asia to give them more than simply an 'exit' option if they are dissatisfied with corporate management. Pursuing this objective are industry-funded groups such as the Asia Corporate Governance Association, formed in 1999 (Asia Corporate Governance Association, 2004), and the Equity Advisory Group of the Institute of International Finance (Institute of International Finance, 2003). The Asian Crisis of the late 1990s provided a strategic opportunity to advance this agenda, as corporate governance reform to protect minority shareholders became a priority of the IMF and other international institutions (Kim, Hwa-Jin, 2001). While this congruence between the interests of foreign institutional investors and the IMF may be simply the natural result of the IMF's policy views, those views themselves are largely shaped by political pressure exerted by the US Treasury (Stiglitz, 2002), which is understandably responsive to the interests of the US financial services industry (see, eg, Stiglitz, 2002: 171-2). The IMF is not the only public institution working to advance the interests of foreign equity investors, however. The Asian Corporate Governance Roundtable, operated by the OECD in collaboration with the World Bank and the Asian Development Bank, pursues a similar shareholder rights agenda (OECD, 2003).

Northeast Asian administrative law reforms have also been supported by external pressures $(\mathrm{Oh}, 2000)$, most recently with respect to national regulation of service industries, such as insurance and banking. Northeast Asian 'administrative guidance' has long been criticised by foreign trading 
partners, who felt that Northeast Asian governments used such informal, unwritten directives to prolong mercantilist industrial policies that they could no longer carry out openly (eg, Johnson, 1982: 242-4). Informal consultative processes between government regulators and the regulated industries were criticised as exclusive and non-transparent, and therefore unfair to outsiders such as foreign investors, and also criticised as vesting too much discretion in government regulators (eg, West, 1992). These concerns were voiced for decades with respect to Japan, South Korea and Taiwan, and are again being heard regarding administrative law issues in relation to China's WTO accession, particularly with respect to the regulation of foreign investment, and with respect to China's commitments to open services markets under the General Agreement on Trade in Services (GATS) (eg, GAO, 2003b; Wilson, 2002).

\section{A Northeast Asian Corporate Governance Reforms: Invigorating Shareholder Derivative Litigation}

Derivative actions are actions brought by corporate shareholders to enforce rights belonging to the corporations in which they own shares. They are a mechanism by which minority shareholders can act on behalf of a corporation when corporate management refuses to act, and are especially useful when a corporation has claims against management that management refuses to pursue. In terms of legal doctrine, efforts to invigorate shareholder derivative litigation in Northeast Asia have focused on amending procedural rules in order to make derivative litigation more economically attractive to potential plaintiff shareholders. Because damages awarded in a derivative suit accrue to the corporation instead of to the shareholders who initiate the action, resort to these suits is especially sensitive to costs potentially borne by plaintiffs. In order to make derivative suits economically attractive Japan, for example, changed its rule on court costs so that in derivative suits court costs are a nominal flat fee rather than a fixed percentage of the amount claimed (Aronson, 2003). South Korea addressed a different disincentive to the bringing of derivative suits by lowering the number of shares that a shareholder has to hold in order to have standing to initiate derivative litigation (Kim, Hwa-Jin, 2001). Taiwan has also moved to overcome economic disincentives to shareholder litigation, in part by lowering the minimum shareholding requirement for derivative litigation (Milhaupt, 2003).

The general thrust of these corporate law reforms has been to shift power away from management and towards minority shareholders, and understood at this level of generality it is easy to see why such reforms attract both Neoliberal and P/P constituencies. Neoliberal interest in corporate governance reform is informed by the view that corporate 
management often enjoys substantial 'slack' in the principal-agent relationship that corporate law envisions as existing between shareholders and management. This view is particularly relevant to Japan, where large corporations often lack a controlling shareholder. In South Korea and Taiwan the Neoliberal interest in derivative litigation is somewhat different, as corporations in these countries are typically controlled by a single shareholder or shareholding family, and thus are not characterised by a separation of ownership and control. In all cases, however, the Neoliberal hope for invigorated derivative litigation is to force management to focus on maximising shareholder value generally, not on the private interests of managers or of controlling shareholders, or on the interests of 'stakeholders' more broadly defined.

This Neoliberal concern receives strong support from foreign interests, bilateral and multilateral. Minority shareholder rights in Japan became a bilateral trade issue in the 1980s, when American investor T Boone Pickens was able to enlist US trade negotiators in his fight with the Koito Corporation. Japan began its legislative effort to invigorate shareholder litigation in the early 1990s, a development that some link to US pressure (eg, Aronson 2003: 24, footnote 56), but it was the Asian Crisis that brought Northeast Asian corporate governance and shareholders' rights into the international spotlight (eg, Claessens et al, 1999). Because it needed IMF assistance during the Crisis, Korea has been subject to the greatest external Neoliberal pressure in this area (Black et al, 2001; Kim, Hwa-Jin, 2001). Taiwan's reforms, while noteworthy, have been the least radical (Milhaupt, 2003).

\section{B Judicialising Northeast Asian Administrative Law}

Administrative law reforms can also be understood as driven by a desire to shift power from bureaucratically organised entities to more particular interests, specifically from state agencies to private actors, or to civil society in a collective sense. Recently enacted administrative procedure statutes in Japan, South Korea and Taiwan seek to impose more stringent requirements on how agencies carry out actions affecting private interests, and in particular seek to impose 'rule of law' benchmarks, such as requiring that regulatory decisions be based on specific, pre-existing legal norms. Allowing the courts to enforce these procedural rights on behalf of private plaintiffs is designed to substantially legalise the relationship between regulatory agencies and civil society. New information disclosure laws ('freedom of information' laws in US terms) are designed to give private actors judicially enforceable rights to information held by state agencies, information that is crucial to understanding, and if necessary 
challenging, administrative action. Like administrative procedure laws, these statutes represent a fundamental shift towards legalisation of the state-civil society interface.

In common with reforms encouraging derivative litigation, administrative law reforms are occurring against a background in which the bureaucratically organised entity, here the government agency, was comparatively unconstrained by law in its dealings with private actors. Students of South Korea and Taiwan would find this claim relatively unremarkable, given that democratisation came only in the late 1980s. Students of Japanese politics will be familiar with Johnson's MITI and the Japanese Miracle (Johnson, 1982) and other 'revisionist' analyses of the Japanese 'developmental state', as well as subsequent attempts to demonstrate that the Japanese ministries involved in the formulation and implementation of economic and trade policies were never insulated from social forces, as the revisionists claimed, but were in fact faithful agents of the long-dominant Liberal Democratic Party (LDP) (Ramseyer and Rosenbluth, 1993). This particular debate, though interesting, focuses on questions of power, rather than on legality. Even if one accepts the thesis that Japan's industrial policy ministries simply did the bidding of the ruling LDP, which in turn did the bidding of voters and contributors, that does not mean that a legalisation of the ways in which the ministries interact with the private sector will not matter for Japanese governance. While it must be true that private actors, particularly large commercial interests, always had more influence vis-à-vis Japan's bureaucrats than one might believe from the more ardent admirers of Japan's 'developmental state', even the most strident critics of the developmental state idea do not claim that that influence was exercised through channels created by administrative law. The promise of administrative law reforms in Northeast Asia is not simply to vest power in private actors, but to legalise and render transparent the channels through which such power is exercised. Of course, the creation of legal mechanisms will not mean that political and social channels will no longer operate. Legal channels will simply provide a new set of options to private actors, leveraging the power already exercised through extra-legal channels.

With respect to Japan, the Neoliberal rationale for administrative law reforms centres on Japan's decade-long economic slump, which can only be cured, the argument goes, by deregulation, liberalisation, and a more rights-oriented society (eg, American Chamber of Commerce in Japan, 2002). Re-revisionist arguments notwithstanding, Asian business interests and their lawyers have consistently expressed the view that administrative guidance was often effectively binding on them, even when it lacked a proper legal basis, because the authorities had mechanisms through which they could punish those who ignored or challenged the guidance (see Chu, 1994; Woo, 1991). With economic agencies delegitimised by the Asian Crisis and Japan's decade-long recession, and with politicians running on 


\section{John K M Obnesorge}

radical reform platforms (even if rarely carried out), the time has come to alter the legal landscape to prevent the government from attempting to 'muddle through' the Crisis. With respect to Northeast Asia more generally, in the Neoliberal view, economic actors demand a 'rule of law' administrative law regime, which maximises the extent to which regulatory activities are limited to those based upon an organised and transparent system of rules, knowable in advance and which does not change unpredictably.

The $\mathrm{P} / \mathrm{P}$ rationale for administrative law reforms, on the other hand, stems from a widespread sense that the 'developmental state' sacrificed democracy and responsiveness on the altar of high-speed growth, in a sense agreeing with the re-revisionists that Japan's ministries never governed in the public interest, insulated from political pressures, but in fact served conservative business interests and their political allies. This refrain is familiar to students of US administrative law, who have long noted that both progressives and conservatives (Liberals) accept the agency capture thesis as descriptively accurate. Operating in the absence of effective administrative law oversight mechanisms, Northeast Asia's government agencies engaged in a number of spectacular failures-such as Japan's AIDS-tainted blood imports fiasco, hazardous discharges from nuclear power plants, and failures in banking regulation-while also being seen as conduits for authoritarian political rule, as in Taiwan and South Korea.

\section{AN AMERICAN CAVEAT}

This chapter represents the early stages of a long-term project to understand the potentially enormous changes being made to Northeast Asia's legal systems, changes which go far beyond those discussed here to include fundamental changes to legal education systems and to the make-up of the national bars, among others. This section seeks to present the background to the author's perspective on these issues, which obviously provides the motivation for the project while also colouring all observations.

One of the common reactions to recent Northeast Asian legal reforms is that they represent 'Americanisation', which seems to refer to both the judicialisation of governance and to an invigorated 'rights consciousness' in Northeast Asian societies. Although the degree to which American models have affected the Northeast Asian reforms is not a focus of this chapter, it is beyond dispute that they have been very important. The idea of 'notice-and-comment' rule-making to allow public participation in the making of agency regulations is a specific example (Tang, 2001), as are the region's initiatives to adopt 'US-style' law schools. At a more abstract level, one also encounters the more general idea that becoming a more rightsconscious, rule of law-oriented society will involve learning from the 
United States (Asahi, 2003). This arguably puts a special burden on Americans studying these reforms, beyond the normal scholarly obligation to be aware of one's own biases and preconceptions. If these reforms are being sold as 'Americanisation' by at least some of their supporters, then Americans might make a positive contribution by speaking candidly about the American experience. A candid assessment of the state of corporate governance and administrative law in the United States should sound a note of caution with respect to judicialisation and the shift of power from management and government agencies.

First, on a general level, sophisticated Northeast Asian scholars are quite aware of the uncertainties involved in social engineering through law, and US critiques of American legal culture are well known. In conversations with Japanese legal scholars, for example, one regularly encounters the idea that Japan does not really want or need US-style legal culture, but that Japan none the less needs to become more 'American' with respect to law. This stance is somewhat troubling, however, in that it seems to presume a greater precision than experience should tell us is really possible when dealing with society-wide legal reforms. There is reason to doubt that the proposed reforms, once they emerge from the legislative process, will bring Japan to some happy medium, achieving just the right amount of 'rights consciousness', without going 'too far'.

With respect to the idea of invigorating derivative litigation, a US perspective also provides some cause for concern. To really activate shareholder derivative litigation will require economic incentives for plaintiffs and for their lawyers. Getting the incentives right will not be easy, as material incentives are made up of a complex constellation of short and long term interests, and as material incentives are also often intermingled with non-economic motives and affected by social norms. An incentive structure too favourable to shareholder derivative suits may well have perverse consequences, consuming corporate time and resources that could be better spent, distracting management from core concerns and making management too risk-averse, and discouraging qualified people from serving as directors. These are common critiques of derivative litigation in the United States, which is seen as driven by plaintiffs' lawyers seeking contingency fees based upon questionable legal claims that management too often agrees to settle (Romano, 1991). Other reforms currently being tried in Northeast Asia, such as increasing the number of independent directors on corporate boards, or mandating more substantial financial disclosures by corporations, may be far more efficient, while relying less on judicialisation.

In addition, the question remains whether $\mathrm{P} / \mathrm{P}$ interests would benefit from a broad shift in Northeast Asian corporate governance towards the shareholder primacy norm, the fundamental Neoliberal goal. Workers may not benefit from such a shift, for example, if shareholder primacy results in 


\section{John K M Obnesorge}

greater focus on stock price based upon short term financial results. It is easy to imagine that such a focus would lead management to resort more readily to lay-offs than historically has been the case in Northeast Asia, or for management to fail to make long-term investments in productivityenhancing new technology. In earlier decades, when it was the Northeast Asian corporation that was ascendant globally, these attributes were cited as sources of comparative strength, and it is certainly worth considering whether they would be put at risk by a greater focus on maximising shareholder value.

With respect to administrative law reforms, the judicialising of American administrative law (which took place to a large extent in the 1960s and 1970s) has not decisively served P/P interests, Neoliberal interests, or the public interest generally. The hope that judicialisation, as part of America's 'due process revolution', would legitimate the administrative state in the eyes of the American public does not seem to have been met. Presidential elections are still won by campaigning against the bureaucracy in Washington, and administrative litigation has become a central aspect of the interest group warfare that seems to drive Americans away from politics. Moreover, judicialising administrative law has furthered the politicisation of the American judiciary, as Americans believe, rightly or wrongly, that a judge's position on the left-right political spectrum is a useful predictor of how aggressively that judge will scrutinise administrative actions that come before him or her on judicial review. As a result, some of the most intense judicial nomination battles now accompany nominations to the Court of Appeals for the District of Columbia, the most important appellate court reviewing federal administrative actions.

If enhanced judicialisation has not allowed US administrative law to successfully legitimate the regulatory welfare state, it is also not clear the judicialisation has enhanced the state's ability to regulate rationally and effectively. In the literature comparing national regulatory approaches and outcomes, the 'adversarial legalism' of the United States often compares unfavourably with regulatory cultures characterised by higher degrees of administrative discretion and negotiation between regulator and regulated, and less frequent resort to the courts (Kagan and Axelrad, 2000). Thus while it is far from clear that Americans are better governed than they would be with a more restricted role for private rights and judicial review, one also suspects that decisions and doctrines will tend to benefit antiregulatory interests over the long term, given that they are likely to be repeat players before the courts, with enormous advantages in terms of resources, and can exercise consistent, targeted focus on the issues important to them. 


\section{WHO'S GETTING WHAT IN NORTHEAST ASIA: A TENTATIVE SCORECARD}

Given the legal changes that have taken place in Northeast Asia, this section seeks to explore which set of interests or concerns, Neoliberal or $\mathrm{P} / \mathrm{P}$, has been met more fully as the reforms have functioned to date. With respect to derivative litigation, $\mathrm{P} / \mathrm{P}$ interests have heartily embraced minority shareholder rights, particularly in Korea, as providing a way to put pressure on corporate management (Milhaupt, 2003; Kim, Jooyoung, 2001). While some Western progressive economists have written favourably about the role of Northeast Asia's corporations (Amsden, 1989), doing so ran the risk of de-emphasising the systematic and often violent suppression of organised labour (Deyo, 1989), and the externalising of enormous environmental costs. To local progressives these corporate faults, together with the tendency of corporate owners to engage in political corruption in support of undemocratic regimes, are all too obvious. If shareholder derivative suits provide a new tool for attacking corporate power when political processes fail, then so much the better. It seems at this stage that derivative litigation is being used more to further $\mathrm{P} / \mathrm{P}$ interests than to simply influence management to pursue shareholder value. First, many of the suits are being brought by what could be called ideological plaintiffs; that is, by public interest lawyers and shareholder activists such as South Korea's People's Solidarity for Participatory Democracy (PSPD). Second, actions are being brought to punish management for specific types of misbehaviour, such as bribery of government officials, illegal payments to extortionists, or truly fraudulent misuse of corporate assets. For example, Japan's Daiwa Bank case arose out of a scandal in Daiwa's US operations that resulted in the bank pleading guilty to a US federal criminal indictment and losing its US banking licences (Aronson, 2003). Similarly, in Korea the basis of the Korea First Bank case was allegedly illegal loans and bribery, and the Samsung litigation was based in part on illegal political contributions (Jang, 2002). In a sense, derivative litigation is being used as a substitute for the criminal justice process that has failed in these areas. Such uses of derivative litigation fit the $\mathrm{P} / \mathrm{P}$ agenda well, but seem unlikely to fundamentally reorient management to focus on maximising shareholder value, the primary Neoliberal concern. For although derivative litigation is being encouraged, it does not appear that the rules have been changed enough to make it really attractive to ordinary profit-oriented lawyers. For example, Northeast Asian lawyers do not appear to be financing the bringing of derivative suits, which contingency fee arrangements facilitate in the United States. In addition, the civil discovery rules are still quite restrictive, so the derivative suits tend to depend on information that has already come to light via criminal investigations or public scandals. Furthermore, the exceptional Daiwa 


\section{John K M Obnesorge}

Bank case that resulted in a multi-million dollar damage award against the Japanese bank's directors has led conservative politicians, supported by business, to seek legislative limits on damage awards (Aronson, 2003). Finally, Northeast Asia's judges tend not to be trained in economics, and are not encouraged to see themselves as innovators in decisions with broad political/economic implications. This suggests that the typical $\mathrm{P} / \mathrm{P}$ cases will be more appealing to them than cases challenging more typical management decisions.

With respect to administrative law reforms, to date these do not appear to have provided business interests, the main focus of Neoliberal concern, with the means to inject the courts into the heart of regulatory governance in the way that administrative law functions in the United States. Business interests are showing an increased tendency towards high-stakes litigation against regulatory agencies, as demonstrated by the suit telecoms carriers have filed challenging a Japanese government rate-setting decision (Aritake, 2003; Belson, 2003). Businesses in Korea, too, are increasingly turning to the courts to challenge specific agency decisions affecting them (Hong, 2000), but such review of licensing and other quasi-adjudicatory decisions is not as challenging to the regulatory agencies as judicially protected rights to participate in the rule-making process. And even in Japan, which has long been a democracy and which began administrative law reforms over a decade ago, companies still complain that they have little legal recourse if a government agency retaliates against them extralegally (Ibison and Nakamoto, 2003).

On the other hand, individuals have succeeded in cases against their governments that a decade ago would have seemed hopeless. A Taiwanese family claimed a high-profile administrative court victory over Taiwan's Ministry of National Defence (Wu, 2003), and a Korean court has ordered the government to compensate a family that was wronged by the Korean CIA in the late 1980s (Lee, 2003). Civil society groups are also making use of the new administrative law statutes, particularly the information disclosure statutes, to address specific instances of public wrong-doing. While $\mathrm{P} / \mathrm{P}$ interests are being furthered by the fact that such uses of administrative law are clearly expanding in Northeast Asia, it remains to be seen whether such specific uses can bring about fundamental change to regulatory governance in Northeast Asia. As noted above, major economic actors are still complaining that they lack legal recourse against targeted enforcement by Japan's tax authorities (Ibison and Nakamoto, 2003), a signal that Japanese ministries may still possess some of the leverage they used, in an earlier era, to 'encourage' compliance with administrative guidance. 


\section{THE RETURN OF POLITICS: ENRON AND SEPTEMBER 11}

The legal reforms discussed here are part of an ongoing globalisation of law. One of the enduring puzzles of globalisation is whether it is more profitably studied as a general phenomenon or trend, or whether it should be studied as the product of many discrete legal and policy decisions, each the result of a particular amalgam of politics and interests. Working in the former vein we seek the big picture, in order to capture the essence of globalisation, but we do so at the risk of fostering a sense of inevitability or determinism. Working in the latter vein we risk missing the big picture, the fact that for the past decade or so the vast majority of such particular legal and policy battles seems to have been won by the forces of globalisation. The legal reforms discussed in this chapter might be seen as part of a wider, inevitable trend, pushed through by a seemingly unstoppable confluence of internal and external forces. In the past few years, however, two things have happened that should call into question the inevitability of this trend. The first of these two events is captured by the name 'Enron', referring not simply to the collapse of the Enron corporation, but to the general crisis in American corporate governance and securities markets that has been unfolding since early in 2001. The second event was the terrorist attacks of September 11, 2001, particularly as the attacks continue to affect American politics and the administration of President Bush. The following passages consider the effects, if any, of Enron and September 11 on reforms such as those discussed in this chapter.

The possible effects of Enron on Northeast Asian corporate law reforms are still unfolding, but three aspects stand out. First, at the level of law reform rhetoric, Enron should take some of the shine off American models, and some of the hubris from American critics of East Asian 'crony capitalism'. The American model of corporate governance, seen as so successful in the 1990s, was exposed as fundamentally flawed at the individual firm level. Many boards of directors, even those with significant numbers of independent directors, failed to monitor and control management in the interests of shareholders. And the preferred method for obtaining results through a reliance on management self-interest (and the use of stock options in management compensation packages) is now viewed as having induced an over-emphasis on stock price, exacerbating the problem of managers inflating corporate earnings figures. One of the features of the Enron crisis has been company after company 'restating' previously announced earnings figures (GAO, 2002), a spectacle that has no doubt contributed to the loss of investor confidence in the US equity markets. This parade of corporate 'restatements' has been matched by a parade of settlement agreements between America's leading financial

institutions and state and federal securities regulators. In only one of several such settlements, J P Morgan Chase and Citigroup agreed to pay 
approximately US\$300 million to state and federal prosecutors to settle charges that they helped Enron manipulate its financial statements to mislead investors (SEC, 2003a).

Enron also exposed socially-embedded, non-universal aspects of the US corporate governance system, as the system was shown to depend for its proper functioning on the functioning of a broader corporate governance community made up of accountants, lawyers, securities analysts, investment banks and others (Coffee, 2002). And once the importance of this wider community of actors was highlighted, we were also reminded that many of these actors perform their proper roles in the general corporate governance environment not because of legal mandates that could be easily transplanted abroad, but as a result of highly evolved webs of professional norms, cultures and practices. In fact, precise legal rules in the area of corporate accounting are now seen as having been one of the causes of the American crisis, seemingly encouraging professionals to abandon their traditional roles in maintaining the integrity of the system. A common post-Enron view is that precise accounting rules encourage financial engineering to comply with the letter of the rules while escaping their regulatory objectives. Reflecting this view, the Sarbanes-Oxley Act instructed the Securities and Exchange Commission (SEC) to conduct a study on standards-based versus rules-based accounting, and in that study SEC staff recommend a shift to principles-based accounting for corporate financial reporting (SEC, 2003b).

Finally, while corruption was most glaringly demonstrated in the numerous frauds committed against shareholders by corporate insiders, Enron also exposed a corrupt undermining of US regulatory structures. Earlier deregulation of energy markets, for example, had resulted in an environment in which energy traders such as Enron were able to manipulate regional energy markets to create false energy shortages (Krugman, 2003b; Krugman, 2003c). In the area of financial market regulation, Enron exposed the fact that the power and resources of the SEC had been allowed to decline substantially, making it more difficult for the SEC to enact new regulations it felt were necessary, or to adequately investigate possible market misbehaviour.

Given the foregoing, an intellectually honest advocate of corporate governance reforms based upon US models would need, post-Enron, to point out that such corporate governance rules will not function as they do in the United States if removed from the US institutional framework, particularly without the 'gatekeeper' professions, and that the proper functioning of that institutional framework depends upon what are, in essence, cultural norms, expectations and practices. Truly adopting US-style corporate governance thus becomes a matter of importing US business and professional culture more generally. This would be a much 
more daunting and controversial prospect than simply adopting a few American-style rules, so one effect of Enron might be to undercut further Americanisation.

Viewed from another angle, however, it seems that Enron will only strengthen the corporate governance reform agenda in Northeast Asia. First, the legislative outcome of Enron, Sarbanes-Oxley, will force a round of adjustments in non-US corporate governance systems for companies that wish to access US capital markets. Sarbanes-Oxley is resulting in a major re-working of the US rules, whether promulgated by Congress, the SEC, or the self-governing securities exchanges, and to the extent that the new rules are more specific than those they are replacing, they will force a higher degree of convergence by foreign systems with the US approach, whatever that may be when the current regulatory initiatives are completed.

Secondly, although Enron exposed major weaknesses in US corporate governance, the weaknesses can be understood in the familiar language of minority shareholder rights, and the solutions can be understood to involve strengthened legal protections for minority shareholders. Asian reform advocates will thus be bolstered by Enron, just as it has added fuel to the fire of shareholder rights advocates in the United States, who are often advocates of shareholder rights abroad (Tassell, 2003). And the depressed US stock market that has resulted from Enron only makes this more likely, as US pension funds and other institutional shareholders are forced to look abroad for profitable investment opportunities, in addition to seeking to reduce risk through diversification in additional markets. In other words, while Enron should raise questions about US corporate governance as practised, it will probably only encourage more energetic advocacy for shareholders' rights, in the United States and abroad. US private equity groups such as Cerberus and Ripplewood have obtained rights to take ownership stakes in Northeast Asian financial institutions, and are showing signs of being willing to exercise their rights in ways that will challenge accepted norms and practices (Ibison and Tett, 2003). US investment funds are also bringing their culture of shareholder activism to Northeast Asia. Sometimes they invest directly, as in the case of Sovereign Asset Management's investment in South Korea's S K Global and the Japanese bank UFJ, and sometimes they invest less directly, as the California employee pension fund CALPERS did in investing US\$200 million to seed a 'corporate governance' fund operated by Sparx Asset Management, a Japanese fund manager (Tassell, 2003). Thus in terms of the reform impulses discussed in this chapter-the P/P and the Neoliberal-Enron can lend support to both.

While Enron's impact seems to basically reinforce Asian corporate governance reforms, September 11 has had three fairly clear effects limiting US reform pressures. The first, and most direct, is that the Bush administration has clearly decided to focus its attention on its 'war on terror', either because terrorism is the most important issue facing the United 
States, or because focusing on terrorism gave Bush the best chance of being re-elected in 2004, a goal which he has now achieved. This focus means that international economic and trade issues are not receiving the attention they did a few years ago. And when the Bush administration does act internationally, it wants to act authoritatively, demanding results, rather than trying to establish institutions and processes that may bring about desired results some time in the future. Trying to bring about desired results in Northeast Asia by encouraging derivative litigation, or more American style administrative law, requires a long-term outlook and a willingness to trust processes and private initiative, rather than demanding results. If it is true that Bush is more inclined than Clinton to demand substantive results, and less likely to accept legal reforms that may eventually lead to those results, American demands for law reforms may become a much less important factor in legislative change in Northeast Asia.

As a result of the resurrection of the importance of strategic interests in US foreign policy, countries that are strategically important to the United States in its 'war on terror' appear to find themselves under somewhat lighter pressure from US trade negotiators, and perhaps from multinational organisations in which the US voice is important. For example, although US authorities found in favour of the first US industry to invoke the new 'market disruption' mechanism for protection against imports from China, President Bush exercised his authority under the statute to deny protection to the complaining industry because he found that protection would not be in the best interests of the United States (US Department of State, 2003). Bush's stated reason for denying the protection was that it would harm other US constituencies, but given that Bush needs China's cooperation in the 'war on terror', this appears to be an instance of strategic interests asserting themselves in trade disputes. Financial commentators, in turn, seem to believe that while Bush is now willing to criticise China for maintaining an overly-weak Renminbi, Japan is able to escape criticism for the manipulation of its currency by virtue of its support for Bush's 'war on terror' (Pilling, 2003). A more controversial example is the new policy of the US Justice Department to challenge law suits brought in US courts by victims of human rights abuses abroad. In the name of preserving relations with our allies, the Justice Department is attempting to block cases brought under the Alien Tort Claims Act and the Torture Victim Protection Act, including a pending case involving slave labour in Burma, prompting public criticism from a Republican member of the Senate Judiciary Committee (Specter, 2003).

A second, less direct, consequence of September 11 has been that it has strengthened the tendencies of the Bush administration towards a conservative, pro-corporate management agenda. This difference between the Bush agenda and the Neoliberalism of the Clinton administration is 
typified by the fact that Bush has appointed CEOs of large, traditional industries to serve as his two Treasury secretaries, while Clinton's most prominent Treasury secretaries were Robert Rubin, a Wall Street investment banker, and Larry Summers, a market-oriented economics professor. Rubin and Summers reportedly occupied key roles in the Clinton administration, while Bush's Treasury secretaries, and the Treasury department as a whole, have been marginalised (Scheiber, 2003; Krugman, 2003a).

This tone set by the Bush administration may be showing up in recent surveys showing that US corporate boards and managers are increasingly willing to criticise Sarbanes-Oxley and the constraints it puts upon them in the name of shareholder protection (Foley and Lardner, 2003; Michaels, 2003a). The more Bush inclines towards the interests of corporate management the more likely he is to accept their argument that Sarbanes-Oxley and related corporate governance reforms are stifling productive corporate initiative (Financial Times, 2004; Michaels, 2004; Buchanan and Donahoe, 2003; Michaels, 2003b; US Law Week, 2003), which will make it less likely that the post-Enron momentum for corporate governance reforms will continue. Evidence that this is happening can be seen in the decision of the US Financial Accounting Supervisory Board to delay implementation of a long-sought reform requiring companies to deduct the cost of employee stock options from profits, a decision that appears to be a direct result of political pressure at the behest of industry (Waters, 2004). A conservative, pro-management agenda aligns Bush with Northeast Asia's traditional business elite, who have every reason to be wary about the explosion of derivative litigation. South Korea's Federation of Korean Industries, for example, funds a think-tank called the Center for Free Enterprise, which warns of the dangers of an aggressive, overtly political, minority shareholders' rights movement (Kim, Chung Ho, 1999).

With respect to administrative law, the conservative tendencies of the Bush administration, strengthened by September 11, could also have important implications. The model of American administrative law that has been most influential internationally is a product of the 1960s and 1970 s, and is tied to the ideology of political pluralism. In that era, when many no longer accepted that government agencies could be trusted to exercise non-political, scientific expertise to govern in the public interest, US administrative law doctrines greatly expanded opportunities for private parties to participate in the administrative process, opportunities enforceable in the courts. The intended effect of these expanded opportunities was to turn the administrative process into a substitute political process, in which the battle among competing social forces would result in appropriate and politically legitimate social policies.

It is widely believed that this vision of the social function of administrative law was the vision of people who believed in the regulatory, social welfare state, but who needed a new ideology, and a new administrative 


\section{John K M Obnesorge}

law, to legitimate such a state once the idea of neutral agency expertise had lost its legitimising power. Such an approach to the regulatory state is anathema to the Bush administration, which is more radical than other Republican administrations in its attempts to roll back the regulatory state, while at the same time rejecting the idea that executive branch processes should be opened up to public scrutiny and contest. In the area of information disclosure, for example, the Homeland Security Act introduced new exceptions to the information disclosure requirements of the Freedom of Information Act (FOIA), ostensibly based upon a desire to keep information about 'critical infrastructure', such as chemical plants, out of the hands of terrorists. Critics, however, have seen these exceptions as an opportunistic, September 11-inspired gift to industry to help it resist environmental activism, prompting Democrats in Congress to introduce legislation to preserve the role of the FOIA (Leahy, 2003; OMB Watch, 2003).

The Bush administration's rejection of the pluralist paradigm has also been apparent in the controversy over the National Energy Policy Development Group (NEPDG), chaired by Vice-President Cheney. Made up of high-level government officials, the NEPDG was directed by President Bush to gather information, deliberate and develop a national energy policy. Rather than soliciting a wide range of views, however, the NEPDG appears to have functioned primarily as a forum for sectors of the energy industry to present their particular proposals with respect to policies affecting them. 'Appears' is the appropriate term, because the administration refuses to disclose who met with the NEPDG, let alone release the minutes of its meetings, even when requested to do so by the General Accounting Office (GAO, subsequently renamed the Government Accountability Office). The GAO was forced to sue the Vice-President under its access-to-records statute, but the suit was dismissed on jurisdictional grounds, ${ }^{1}$ and the GAO was relegated to writing a superficial report based on fragments of information it had been able to collect from secondary sources (GAO, 2003a; Sevastopulo, 2003; Seelye, 2003). In its unwillingness to open the NEPDG process to public scrutiny, the administration is demonstrating a fundamental disdain for pluralist assumptions, apparently unconcerned with maintaining even the façade of a pluralist process to legitimate its substantive policy decisions.

In tandem with its tendency to reject pluralist assumptions regarding the transparency of executive branch activities, the Bush administration has also shown itself willing to disregard established understandings in its efforts to bend the administrative agencies to its will. The innocuously titled Data Quality Act of 2000, passed by an uninformed Congress after

1 Walker $v$ Cheney, 230 F Supp 2d 51 (DDC 2002). 
being inserted into a massive appropriations bill at the behest of an industry lobbyist (Mooney, 2004; Adams, 2002), is being implemented by officials in the White House Office of Management and Budget in ways that force federal agencies to respond to sometimes spurious private sector challenges to agency science (Weiss, 2004). The perception, driven only in part by controversy over the Data Quality Act, that the Bush administration is willing to subject scientific objectivity within administrative agencies to partisan politics has driven many senior figures in the scientific community into active opposition (Revkin, 2004; Union of Concerned Scientists, 2004). In addition, officials in the Bush administration have twice been publicly rebuked by the GAO for illegally interfering with administrative agencies: once for illegally preventing a Medicare actuary from revealing to Congress the true costs of the administration's Medicare reforms (Pear, 2004; GAO, 2004b), and once for illegally using Medicare funds to produce propaganda for the same reforms disguised as news reports (GAO, 2004b).

In step with the Bush administration, conservative political activists are likewise demonstrating a clear willingness to attack the pluralist assumptions embedded in US administrative law and the regulatory process, launching initiatives such as 'NGO Watch', challenging the legitimacy of consultation with public interest NGOs whose participation in policymaking has been understood as central to pluralist understandings. Finally, to the dismay of even mainstream conservatives such as US Supreme Court Chief Justice Rehnquist, radical conservatives have taken a number of actions to limit judicial discretion in criminal sentencing, actions that in their heavy-handedness challenge the independence of individual federal judges, and thus the judiciary as a whole (Perine, 2004; Walsh and Eggen, 2003; Lore, 2003; Cambanis, 2003).

Whether any of these US developments matters for Northeast Asia is, of course, a different question. One of the fundamental premises of this chapter is that formally similar legal norms and institutions take on lives of their own when adopted in disparate societies. Even if one accepts that US interests have played a large role in supporting Northeast Asia's administrative and corporate law reforms, and did so primarily to further Neoliberal impulses, it is likely that the way these legal fields actually function now in the United States is irrelevant to Northeast Asia. Perhaps the primary way the conservatism of the Bush administration could influence the functioning of these doctrines in Northeast Asia would be by helping conservative, pro-business political parties win national elections. Bush tried but failed to help the conservative candidate in South Korea's December 2002 presidential election, so this sort of US influence is a possibility. Left-leaning Korean President Roh Moo-hyun is currently battling Korean business interests to expand the investigative authority of 


\section{John K M Obnesorge}

Korea's Fair Trade Commission (Park, 2003), and if the Bush administration had been able to tip the election to the conservative candidate this battle might never have been fought. On the whole, though, it is very hard to draw clear connections between developments in the United States and changes in specific legal fields in Northeast Asia.

\section{CONCLUSION}

Eclectic critique asks us to set aside preconceived notions when we think about law reform. One way to do this is to recognise that legal rules and institutions may carry within them the potential to operate in dramatically different ways, and that we cannot fully evaluate the results of legal reform projects until we can see how newly-adopted norms and institutions function. And reforms that depend upon judicialisation, which seek to bring about social change by harnessing private interests channelled through the litigation process, are especially subject to unintended consequences. This chapter has adopted the highly stylised dichotomy of Neoliberal and P/P concerns to help structure an eclectic critique of corporate and administrative law reforms in Northeast Asia. A tentative conclusion reached from applying this structure is that reforms that might well be driven by a Neoliberal agenda can turn out to be very useful to local P/P forces, who may be able to make greater use of such reforms, when these are localised, than could Neoliberal interests. But precisely because the reforms discussed here carry within them the potential to further either Neoliberal or P/P interests, the admonition 'be careful what you wish for' is particularly appropriate. A second conclusion is that September 11 may well slow down the Neoliberal legal agenda globally. Whether that is a good thing depends upon what replaces Neoliberalism, but there is reason to believe that we may look back on the Neoliberal hegemony of the 1990 s, with all its faults, as more positive and constructive than what followed.

\section{BIBLIOGRAPHY}

ADAMS, REBECCA (2002) 'Federal Regulations Face Assault on Their Foundation' 10 August 2002) 60 Congressional Quarterly Weekly 2182.

AMERICAN CHAMBER OF COMMERCE IN JAPAN (October 2002) 'Improve Japan's Civil Judicial Process and Legal Services System' Viewpoint (copy on file with author).

Amsden, Alice H (1989) Asia's Next Giant: South Korea and Late Industrialization (Oxford University Press, Oxford). 
ARITAKe, TOSHIO (2003) 'NTT Carriers Sue Japanese Government on NTT Rate Rise' (24 July 2003) 20 International Trade Reporter 1268.

ARONSON, BRUCE E (2003) 'Reconsidering the Importance of Law in Japanese Corporate Governance: Evidence from the Daiwa Bank Shareholder Derivative Case' 36 Cornell International Law Journal 11 (2003-2004).

ASAHI SHIMBUN (2003): 'Editorial: Education in Rule of Law' Asahi Shimbun (English language Internet edition) 19 August 2003, available at: <http://www.asahi.com/english/op-ed/K2003081900269.html> last accessed 19 August 2003 (copy on file with author).

ASIa CORPORATE GOVERnANCE ASSOCIATION (2004) 'Facilitating Effective Corporate Governance in Asia,' available at: <http://www.acgaasia.org/loadfile.cfm?SITE_FILE_ID=247>, last accessed 15 November 2006.

Belson, Ken (2003) 'Japan Phone Case to Pit Business Against Bureaucrats' New York Times 15 July 2003, W1, col 3.

BLACK, BERNARD ET AL (2001) 'Corporate Governance in Korea at the Millennium: Enhancing International Competitiveness' 26 Journal of Corporation Law 546.

Buchanan, Robin and Donahoe, John (2003) 'Boards Will be Frozen by Caution's Icy Hand' Financial Times 30 July 2003, 13, col 1.

CAMBANIS, Thanassis (2003) 'Sentencing Law Targets U.S. Judges in Massachusetts' Boston Globe 30 May 2003, A1.

CHU, YUN-HAN (1994) 'The Realignment of Business-Government Relations and Regime Transition in Taiwan' in Andrew Macintyre (ed) Business and Government in Industrialising Asia (Cornell University, Ithaca, NY).

Claessens, Stijn; Djankov, Simeon; and Lang, LaRRy H P (1999) 'Who Controls East Asian Corporations? World Bank Policy Research Working Paper 2054, February, 1999.

COFFEe, JOHN C JR (2002) 'Understanding Enron: It's About the Gatekeepers, Stupid' Columbia Law School, Center for Law and Economic Studies, Working Paper No 207, 30 July 2002, available at: <http:// ssrn.com/abstract_it=325240>, last accessed 15 November 2006.

DEYO, FREDERIC C (1989) Beneath the Miracle: Labor Subordination in the New Asian Industrialism (University of California, Berkeley, CA).

EPSTEIN, RICHARD A (1995) Simple Rules for a Complex World (Harvard University, Cambridge, MA).

Financial Times (2004) 'The boardroom burden: calls for reform are replaced by concern that corporate shake-up has gone too far' Financial Times 1 June 2004, 9, col 1. 
FOLEY and LARDNER 'Sarbanes-Oxley Shapshot Survey' (2003), available at: <http://view.exacttarget.com/?j=144371\&l=72857_HTML\&e= tandrlik@webershandwick.com>, last accessed 30 July 2003 (copy on file with author).

FRIEDMAN, LAWRENCE M (1990) The Republic of Choice (Harvard University, Cambridge, MA).

General ACCOUnTing OfFice (2002) 'Financial Statement Restatements' Report to the Chairman, Committee on Banking, Housing, and Urban Affairs, US Senate, October 2002. GAO-03-138.

- (2003a) 'Energy Task Force: Process Used to Develop the National Energy Policy' Report to Congressional Requesters, August 2003. GAO-03-894.

— (2003b) 'World Trade Organization: Ensuring China's Compliance Requires a Sustained and Multifaceted Approach' Statement of Loren Yeger, Director, International Affairs and Trade, October 2003. GAO-04-172T.

— (2004a) 'Department of Health and Human Services - Chief Actuary's Communications with Congress' Legal Opinion from GAO General Counsel Anthony H Gamboa to members of Congress, 7 September 2004. GAO-B-302-911

— (2004b) 'Department of Health and Human Services, Centers for Medicare \& Medicaid Services-Video News Releases' Decision of the Comptroller General of the United States, 19 May 2004. GAOB-302710.

HONG, JOON-HYUNG (2000) 'Administrative Law in the Institutionalized Administrative State' in Dae-Kyu Yoon (ed) Recent Transformations in Korean Law and Society (Seoul National University, Seoul).

IBISON, DAVID and NAKAMOTO, MichiYO 'Japanese Tax Bill for Lone Star Worries Foreign Funds' Financial Times 17 July 2003, 29.

IBISON, DAVID and TeTT, GILLIAN (2003) 'American to Head Japan's Aozora Bank’ Financial Times 23 July 2003, Companies and Markets 1.

InSTITUTE OF InTERNATIONAL FInANCE, InCORPORATED (2003) 'Corporate Governance in Korea: An Investor Perspective’ IIF Equity Advisory Group Task Force Report (July, 2003) (copy on file with author).

JANG, HASUNG (2002) 'Empowering Shareholders Rights: Derivative and Class-Action Lawsuits,' presentation to the OECD Asian Roundtable on Corporate Governance, Mumbai, India (11-12 November 2002) (copy on file with author).

JOHNSON, CHALMERS (1982) MITI and the Japanese Miracle (Stanford University, Stanford, CA).

Kagan, Robert A and AXelRAd, LeE (eds) (2000) Regulatory Encounters: Multinational Corporations and American Adversarial Legalism (University of California, Berkeley CA). 
KIM, Chung Ho (1999) 'A Thought on Corporate Governance Movements' Center for Free Enterprise Executive Essay, No EE-25, 19 January 1999, available at: <http://www.cfe.org/English/Briefsbbs/ essay/content.asp?idx=146>, last accessed 20 October 2004 (copy on file with author).

KIM, Hwa-Jin (2001) 'Taking International Soft Law Seriously: Its Implications for Global Convergence in Corporate Governance' 1(1) Journal of Korean Law 1.

KIM, JoOyoung and KIM, JoONGO (2001) 'Shareholder Activism in Korea: A Review of How PSPD Has Used Legal Measures to Strengthen Korean Corporate Governance' 1(1) Journal of Korean Law 51.

Krugman, Paul (2003a) 'Everything Is Political' New York Times 5 August 2003, A15, col 6.

_ (2003b) 'The Road to Ruin' New York Times 19 August 2003, A21, col 5 .

— $(2003 \mathrm{c})$ 'Another Friday Outrage' New York Times 1 September 2003, A23, col 6.

LEAHY, PATRICK (2003a) 'Restoration of Freedom of Information Act ('Restore FOIA') Sectional Analysis' available at: <http://leahy.senate. gov/press/200303/031203c.html>, last accessed 15 November 2006.

LeE, SANG-EON (2003) 'Susie Kim's Retribution' JoongAng Daily 15 August 2003.

LORE, MiCHELLE (2003) 'Amendment Limiting Judicial Discretion in Sentencing Receives Cool Reception from Judges' Minnesota Lawyer 7 July 2003.

MiCHAELS, ADRIAN (2003a) 'Reforms Lose Support of Business Leaders' Financial Times 28 July 2003, 16, col 1.

— (2003b) 'Boardroom proposals clash with turn of corporate tide' Financial Times 27 August 2003, 14, col 1.

- (2004) 'AIG chairman bemoans burden of governance' Financial Times 20 May 2004, 19, col 6.

MilHAUPT, CURTIS J (2003) Non-profit Organizations as Investor Protection: Economic Theory, and Evidence from East Asia (unpublished manuscript, copy on file with author).

MOONEY, CHRIs (2004) 'Paralysis by Analysis' (1 May 2004) 36(5) Washington Monthly 23.

NGO WATCH: <http://www.ngowatch.org>, last accessed 15 November 2006.

ORGANISATION FOR ECONOMIC COOPERATION and DEVELOPMENT (2003) 'White Paper on Corporate Governance in Asia', available at: <http:// www.oecd.org/dataoecd/48/55/25778905. pdf>, last accessed 15 November 2006. 
OH, Jun-GeN (2000) 'The Characteristics and Results of Korea's Administrative Regulations Reform' in Dae-Kyu Yoon (ed) Recent Transformations in Korean Law and Society (Seoul National University, Seoul) 73. (2003) 'The Rule of Law, Economic Development, and the Developmental States of Northeast Asia' in Christoph Antons (ed) Law and Development in East and Southeast Asia (RoutledgeCurzon, London).

OMB Watch (2003) 'American Chemistry Council's Comments Demonstrate Need for Public CII Docket' 28 July 2003, available at: <http:// www.ombwatch.org/article/articleview/ 1697/1/252?TopicID=1>, last accessed 15 November 2006.

PARK, SANG-SOO (2003) 'New Holding Firm Rule Aims at Simpler Chaebol System' Korea Herald 19 August 2003, availlable at: <http://www.koreaherald.co.kr/SITE/data/html_dir/2003/08/20/20030 8200051.asp >, last accessed 15 November 2006.

PeAR, Robert (2004) 'Inquiry Proposes Penalties for Hiding Medicare Data' New York Times 8 September 2004, A16, col 5.

Perine, KeITH (2004) “"Heightened Tensions” Fray Judicial-Legislative Relations' (18 September 2004) 61 Congressional Quarterly Weekly 2148.

Pilling, David (2003) 'Snow Calls on Beijing to Let Currency Float' Financial Times 2 September 2003, 1, col 2.

RAMSEYER, MARK (2003) Comment as Panelist, at the Sharing Scholarship on East Asian Law Conference, Harvard Law School, Cambridge, Massachusetts, May 2003.

Ramseyer, Mark, and Rosenbluth, Frances McCall (1993) Japan's Political Marketplace (Harvard University, Cambridge, MA).

REVKIN, ANDREW C (2004) "Bush vs. the Laureates: How Science Became a Partisan Issue' New York Times 19 October 2004, D1, col 1.

ROMANO, ROBERTA (1991) 'The Shareholder Suit: Litigation without Foundation?' 7 Journal of Law, Economics and Organization 55.

SCHEIBER, NoAm (2003) 'Is Snow Worse Than O'Neill?: Buried Treasury' New Republic 11 August 2003, 17-21.

SECURITIES and EXCHANGE COMMISSION (2003a) 'SEC Settles Enforcement Proceedings against J.P. Morgan Chase and Citigroup' SEC Press Release, 28 July 2003, available at: <http://www.sec.gov/news/press/ 2003-87.htm>, last accessed 15 November 2006.

- (2003b) 'SEC Study on Adoption by the U.S. Financial Reporting System of a Principles-Based Accounting System' SEC Press Release, 25 July 2003, available at: <http://www.sec.gov/news/press/200386.htm>, last accessed 15 November 2006. 
Seelye, Katherine Q (2003) 'Study Confirms "Stakeholders" Gave Advice to Energy Panel' New York Times 26 August 2003, A16, col 5. Sevastopulo, DEMETRI (2003) 'GAO Investigation: Cheney office attacked on energy probe' Financial Times 27 August 2003, 2, col 8.

SPECTER, ARLEN (2003) 'The Court of Last Resort' New York Times 7 August 2003, A23, col 1.

STiglitz, JosepH E (2002) Globalization and its Discontents (Penguin Books, London and New York).

TANG, Dennis T C (2001) 'Overview of the Administrative Procedure Act of Taiwan' Presentation to the Alexander von Humbolt Foundation, September, 2001, Taipei, Taiwan, available at: <http://www.avh.de/en/ netzwerk/veranstalt/hoersaal/2001_taiwan_01.htm>, last accessed 26 July 2002 (copy on file with author).

Tassell, Tony (2003) 'Japan Gets to Grips with Corporate Governance' Financial Times 28 July 2003, 20, col 5.

TrubeK, David M and Galanter, Marc (1974) 'Scholars in SelfEstrangement: Some Reflections on the Crisis in Law and Development Studies in the United States' [1974] Wisconsin Law Review 1062.

US Law Week (2003) 'SEC Chairman Tries to Allay Concerns That Sarbanes-Oxley Increases Liability' 72(4) US Law Week 2056-58.

UnION OF CONCERNED SCIENTISTS (2004) 'Scientific Integrity in Policy Making: Further Investigation of the Bush Administration's Abuse of Science' (July 2004) available at: <http://www.ucsusa.org/ global_environment/rsi/page.cfm?pageID=1449>, last accessed 4 November 2004 (copy on file with author).

United STATES DEPARTMENT OF STATE, INTERNATIONAL INFORMATION PRograms (2003) 'Bush Forgoes Action on Imports of Chinese Devices' Washington File, 21 January 2003 available in the Public Diplomacy Query Archive: <http://usinfo.state.gov/products/pdq/ wfarchive. htm>, last accessed 31 July 2003 (copy on file with author).

WALSH, EDWARD and EGgEN, DAN (2003) "Ashcroft Orders Tally of Lighter Sentences; Critics Say He Wants "Blacklist” of Judges' Washington Post 7 August 2003, A01.

WATERS, RICHARD (2004) 'FASB postpones stock options rule' Financial Times 14 October 2004, 1, col 2.

WeISS, RICK (2004) “"Data Quality” Law is Nemesis of Regulation Washington Post 16 August 2004, A01.

WeSt, JAMES M (1992) 'Administrative Procedure in Korea' Journal of the American Chamber of Commerce in Korea (December 1992)

WILSON, JEFFREY (2002) 'Insurance regime undermines China's WTO credentials' 21 International Financial Law Review 35 (February 2002).

Woo, JunG-EN (1991) Race to the Swift: State and Finance in Korean Industrialization (Columbia University, New York). 


\section{John K M Ohnesorge}

WU, SOFIA (2003) 'MND Loses Appeal for Return of Pension Paid to Defector's Family' Central News Agency, Taiwan, 6 August 2003. 